Research Report No. 1/2012

\title{
Transnational Comparisons: Theory and Practice of Comparative Law as a Critique of Global Governance
}

Peer Zumbansen

Osgoode Hall Law School of York University, PZumbansen@osgoode.yorku.ca

Follow this and additional works at: http:// digitalcommons.osgoode.yorku.ca/clpe

\section{Recommended Citation}

Zumbansen, Peer, "Transnational Comparisons: Theory and Practice of Comparative Law as a Critique of Global Governance" (2012). Comparative Research in Law \& Political Economy. Research Paper No. 1/2012.

http://digitalcommons.osgoode.yorku.ca/clpe/3 


\section{OSGOODE}

OSGOODE HALL LAW SCHOOL

YOR K UN I VERS I T Y

\section{OSGOODE HALL LAW SCHOOL}

Comparative Research in Law \& Political Economy

RESEARCH PAPER SERIES

Research Paper No. 1/2012

Transnational Comparisons: Theory and Practice of Comparative Law as a Critique of Global Governance

Peer Zumbansen

Editors:

Peer Zumbansen (Osgoode Hall Law School, Toronto, Director Comparative Research in Law and Political Economy)

John W. Cioffi (University of California at Riverside)

Leeanne Footman (Osgoode Hall Law School, Toronto, Production Editor)

Comparative Research in Law \& Political Economy 


\title{
TRANSNATIONAL COMPARISONS: THEORY AND PRACTICE OF COMPARATIVE LAW AS A CRITIQUE OF GLOBAL GOVERNANCE•
}

\author{
Peer Zumbansen ${ }^{*}$
}

\begin{abstract}
A project seeking to assert and contrast the 'practice' of comparative law in distinction from the well-known and longstanding theoretical critique of the field is itself in need to define the meaning of practice. The following chapter, written for a volume edited by Jacco Bomhoff and Maurice Adams, takes up this challenge in two steps. In a first one, it revisits comparative law's seemingly eternal self-doubt regarding its target of inquiry and its method. I will suggest that there is a great promise for comparative legal studies in the context of transnational legal pluralism as a methodological approach to the study of intersecting normative and institutional orders. In a second step, I would like to draw out the context in which current debates about comparative and transnational law are unfolding. This context- 'global governance'- poses significant challenges for the role of law in what has fast become a multi-disciplinary inquiry regarding the contours and foundations of a continuously evolving global regulatory landscape. A reflection on the regulatory aims of comparative law as transnational law, which I have been pursuing together with Russell Miller in 'Comparative Law as Transnational Law: A Decade of the German Law Journal' (Oxford University Press, 2012), can serve as a powerful critique of global governance.
\end{abstract}

Keywords: comparative law, comparative constitutional law, practice, transnational law, constitutionalism

JEL: K10, K33

\section{Introduction}

In 1997, in a thoughtful and provocative article, Günter Frankenberg raised the question 'Why Care'? in relation to the vivid debates concerning the uncertain future

\footnotetext{
- This chapter takes up questions from a larger research inquiry into the methodology and prospects of comparative and transnational law. Parts draw and build on ideas addressed in the following essays: Carving out Typologies - Accounting for Differences across Systems: Towards a Methodology of Transnational Constitutionalism, in: Michel Rosenfeld and Andras Sajo (eds.), Oxford Handbook of Comparative Constitutional Law (Oxford University Press, 2012 - forthcoming), 'Varieties of Comparative and Global Constitutionalism: The Emergence of a Transnational Legal-Pluralist-Order', in 1:1Global Constitutionalism (2012) - forthcoming, and 'Neither 'Public' Nor 'Private', 'National' nor 'International': Transnational Corporate Governance from a Legal Pluralist Perspective', 38:1 Journal of Law and Society (2011), 50-75. I am grateful to Alexandra Kemmerer for a close and critical reading of this text.

* Osgoode Hall Law School, York University, Toronto, Canada. 2011, Hanse Institute for Advanced Study, (www.h-w-k.de). Email: PZumbansen@,osgoode.yorku.ca.
} 
and legacies of the welfare state. ${ }^{1}$ Take away a few years, consider a slight change in that title by adding three letters, and the question asked was: 'Why Compare'?, an invitation to an inquiry, which has arguably been at the centre both of that very same scholar's milestone article in $1985^{2}$ and of the field's very own self-assertion and introspection. ${ }^{3}$ Indeed, comparative lawyers have for more than one-hundred years sought to increase the understanding of 'foreign' legal orders and regulatory systems. Despite some never fully resolved methodological questions, ${ }^{4}$ great advances have been made in the comparative study of different regulatory areas both in 'private' (contract, tort, corporate, labor) and 'public' law (constitutional law, environmental law). These areas illustrate that comparative law is the opposite from l'art pour l'art. Quite to the contrary, comparative work in these realms has been occurring and progressing at particular moments in time. Scholars and practitioners have been looking to the particulars of a 'foreign' legal order in the awareness that there is something at stake and that a comparative perspective on a set of legal rules, principles or institutions would, ultimately, produce important insights not only into the differences and similarities of the compared legal cultures, but - more significantly - into the complex manner in which legal orders evolve. To the degree that the comparativist would 'discover' and 'learn' about the rules, institutions and legal routines in 'foreign' lands, she would most importantly find herself thrown back unto herself, confronted with her own idiosyncrasies, her background and 'culture', eventually becoming much less starry-eyed vis-à-vis her own legal system. ${ }^{5}$ Despite the persistence with which protagonists of comparative ${ }^{6}$ or 'world' law ${ }^{7}$ continued to make claims of law's universal progress, doubt inevitably began to creep into an ever more elaborate edifice of comparative law, and not before long the well-meaning, yet ideologically naïve impetus of comparative law was aptly exposed and laid out for all to see. ${ }^{8}$

Meanwhile, now at just over 110 years old, comparative law is not dead - or, is it? ${ }^{9}$ As an element of crucial importance in a system of considerably parochial national legal education, ${ }^{10}$ the value of comparative law can be and is often still highlighted with view to the graduating students' need to 'know more about the

\footnotetext{
${ }^{1}$ Günter Frankenberg, 'Why Care? - The Trouble with Social Rights', Cardozo Law Review, 17 (1996), 1365-1390.

${ }^{2}$ Günter Frankenberg, 'Critical Comparisons: Re-Thinking Comparative Law', Harvard International Law Journal, 26 (1985), 411-455.

${ }^{3}$ Peer Zumbansen, 'Comparative Law's Coming of Age? Twenty Years after "Critical Comparisons"', German Law Journal 6 (2005), 1073-1084.

${ }^{4}$ For an excellent overview, see Ralf Michaels, 'The Functional Method in Comparative Law', in Mathias Reimann and Reinhard Zimmermann (eds.), Oxford Handbook of Comparative Law (Oxford University Press, 2006).

${ }^{5}$ Frankenberg, 'Critical comparison'.

${ }^{6}$ Konrad Zweigert and Hein Kötz, An Introduction to Comparative Law, 3rd ed. (Oxford University Press, 1996).

${ }^{7}$ Harold J. Berman, 'World Law', Fordham International Law Journal, 18 (1995), 1617-1622.

${ }^{8}$ Otto Kahn-Freund, 'On Uses and Misuses of Comparative Law', Modern Law Review, 37 (1974), 127; Jonathan Hill, 'Comparative Law, Law Reform and Legal Theory', Oxford Journal of Legal Studies, 9 (1989), 101-115; Frankenberg, 'Why care?'.

${ }^{9}$ But, see the sobering notes by Ralf Michaels, 'Im Westen nichts Neues?', RabelsZ, 66 (2003), 97-115

10 See the contributions to the $10^{\text {th }}$ Anniversary German Law Journal Symposium on 'The Transnationalization of Legal Cultures', June-July 2009, 1291-1416, available at: http://www.germanlawjournal.com/pdfs/FullIssues/PDF_Vol_10 No_10_Complete\%20Issue.pdf.
} 
world ${ }^{11}$ and to be better equipped to aptly move from one 'secondment' to the next. ${ }^{12}$ And yet, comparative law in its own right is not on the rise in law school faculties around the world, surely not as a mandatory subject or, as such, in high demand from students. The last significant creation of a journal dedicated to the comparative study of law goes back to the initiative of a group of established legal scholars ${ }^{13}$ - quite the opposite from an innovative grass roots movement driven by the 'next generation'.

The question whether that can be solely accredited to the field's never-ending methodological self-doubts ${ }^{14}$ or to the overwhelming influence of practitioner lobbying over law school curricula with view to include more practical training opportunities in the students' legal education ${ }^{15}$ does not necessitate a satisfying or clear-cut answer. Legal education, for the time being, continues to struggle to build into daily taught subjects a genuinely comparative perspective, from which it would be possible for students to both contextualize and relativize what it is they are learning about the law in their own legal culture.

This shortcoming is regrettable in that legal practice appears to ever more naturally be exposed to elements and trends arising from an evolving and increasingly interdependent transnational legal-pluralist order. The core trait of this emerging order is its ambiguous, nervous nature. Evolving out of a parallel and overlapping processes of state transformation, mostly in the 'North' and the 'West', and decolonization, consolidation and transition in the 'South', the emerging elements of normativity and of institutional order prompt a serious revisiting of comparative law's traditional starting points. The questions of method remain inseparable from those concerning the politics and the "project' 16 of any comparative undertaking. And, from that vantage point, a legal methodological introspection as has long been part of the 'fledgling' discipline of comparative law, ${ }^{17}$ is inevitably further complicated by the fact that the jurisdictional reference points are themselves becoming less reliable as demarcating lines. Neither a nationally confined doctrinal instruction in the rules and methods of a particular field in a given country nor the, more often than not, relatively randomly chosen jurisdiction of comparison, ${ }^{18}$ can provide for an adequate training of the soon to graduate legal scholar - or practitioner.

While law schools continue to struggle with the challenges of 'globalization', ${ }^{19}$ the reality of a fast integrating world still raises the bar for such an

\footnotetext{
${ }^{11}$ Catherine Valcke, 'Global Law Teaching', Journal of Legal Education, 54 (2004), 160; Mathias Reimann, 'From the Law of Nations to Transnational Law: Why We Need a New Basic Course for the International Curriculum', Penn State International Law Review, 22 (2004), 397-415

${ }^{12}$ Roy T. Stuckey, 'Preparing Students to Practice Law: A Global Problem in Need of Global Solutions', South Texas Law Review, 43 (2002), 649.

${ }^{13} \mathrm{http}: / /$ www.ejcl.org/.

${ }^{14}$ Annelise Riles, 'Introduction: The Projects of Comparison', in Annelise Riles (ed.), Rethinking the Masters of Comparative Law (Oxford: Hart Publishing, 2001), p. 2: “...everyone is a methodologist to be a comparativist today is to worry about the proper terms, categories, scale, methods, and data to be used in comparison."

${ }^{15}$ See eg 'Washington and Lee School of Law Announces Dramatic Third Year Reform', 10 March 2008, available at: http://law.wlu.edu/news/storydetail.asp?id=376.

${ }^{16}$ Annelise Riles, 'Introduction: The Projects of Comparison', in: Annelise Riles (ed.) Rethinking the Masters of Comparative Law (Oxford: Hart Publishing, 2001); see also Otto Kahn-Freund, 'On Uses and Misuses of Comparative Law', Modern Law Review, 37 (1974), 1-27.

${ }^{17}$ Riles, 'The Projects of Comparison', p. 6.

${ }^{18}$ In many cases going back to the personal acquaintances between scholars.

19 Simon Chesterman, 'The Globalisation of Legal Education', Singapore Journal of Legal Studies (2008), 58-67; Craig Scott, 'A Core Curriculum for the Transnational Legal Education of JD and LLB Students: Surveying the Approach of the International, Comparative and Transnational Law Program at Osgoode Hall Law School', Penn State International Law Review, 23 (2005), 757-773.
} 
endeavor significantly. Above all, this 'reality' reflects deep-running transformations of the normative and institutional regulatory landscape. Where comparative lawyers traditionally directed their gaze at the intricate histories of a nation's legal culture, iterations and turning points in the hope to gain insights into the driving forces of evolving legal and political cultures, ${ }^{20}$ this process is today still more difficult in light of the relativization of jurisdictional boundaries as markers of rule-generating and administering spaces. ${ }^{21}$ What Philip Jessup, in 1956, identified as the emergence of 'Transnational Law', 22 today shows its face as a myriad web and 'assemblage' ${ }^{, 2}$ of intertwining, both public and private, that is hybrid, forms of regulation that can no longer be easily associated with one particular country or, for that matter, one officially mandated rule making authority. ${ }^{24}$ The challenge arising from this transnational legal-pluralist order consists in making sense of different understandings of legal rule-making, legal pluralism and the role of political authority (eg the 'state') in the face of an increasingly fluid normative order.

In the remainder of this chapter I will very briefly consider four areas situated in this ambiguous space between comparative law and transnational legal pluralism. In understanding these fields as having both a mediating and catalyzing function in provoking inquiries into the prospects of legal method under conditions of globalization, they offer valuable insights into the dynamics between theory and practice of 'comparative' law. The fields considered in the following are: comparative corporate governance; human rights law and legal anthropology; comparative constitutional law; and comparative administrative law through the lens of 'Global Administrative Law'.

\section{Comparisons in a Transnational Legal-Pluralist Order}

The question that comparative lawyers have to ask themselves is how to adopt their analytical toolkit to the realities of a largely fragmented and incoherent regulatory landscape. The contours of the emerging multi-layered, pluralist regulatory architecture become visible through a closer look at some of the most dynamic legal regulatory areas today. In manifold fields of legal regulation, including contract, ${ }^{25}$ tort, ${ }^{26}$ environmental ${ }^{27}$ or corporate law, ${ }^{28}$ we have been able to witness a remarkable

\footnotetext{
${ }^{20}$ Annelise Riles, 'Introduction: The Projects of Comparison', p. 11: 'The comparative lawyer is a person who engages comparison for a purpose, in other words, whether it is to find a model for modernization, or to harmonize legal regimes.'

${ }^{21}$ Karen Knop, Ralf Michaels and Annelise Riles, 'Transdisciplinary Conflict of Laws: Introduction', Law \& Contemporary Problems, 71 (2008), 1-17.

${ }^{22}$ Philip C. Jessup, Transnational Law (Yale University Press, 1956).

${ }^{23}$ Saskia Sassen, Territory - Authority - Rights. From Medieval to Global Assemblages (Princeton University Press, 2006); Marc Amstutz, 'In-Between Worlds: Marleasing and the Emergence of Interlegality in Legal Reasoning', European Law Journal, 11 (2005), 766-784.

${ }^{24}$ Larry Catá-Backer, Governance without Government: An Overview, in: G. Handl, J. Zekoll \& P. Zumbansen (eds.), Beyond Territoriality: Transnational Legal Authority in an Age of Globalization (Brill, 2012 - forthcoming); Peer Zumbansen, 'Neither 'Public' nor 'Private', 50-75.

${ }^{25}$ W. Carl Kester, 'Governance, Contracting, and Investment Horizons: A Look at Japan and Germany', in Donald H. Chew (ed.) Studies in International Corporate Finance and Governance Systems. A Comparison of the U.S., Japan and Europe (Oxford University Press, 1997).

${ }^{26}$ Craig M. Scott, 'Introduction to Torture as Tort: From Sudan to Canada to Somalia', in Craig M. Scott (ed.) Torture as Tort (Oxford: Hart Publishing, 2001).

${ }^{27}$ Jutta Brunnée, 'Of Sense and Sensibility: Reflections on International Liability Regimes as Tools for Environmental Protection', International and Comparative Law Quarterly, 53 (2004), 351-367.
} 
expansion of the outside boundaries of the respective fields to elements of comparison, integration and assimilation. This development goes far beyond the traditional zeal of comparative law, in that experts in a particular field now find themselves unavoidably confronted with a fast-changing regulatory and institutional landscape, the driving forces of which might have their origin within the particular legal culture or, more likely, result from a combination of elements of national and transnational regulatory evolution. In this space, it becomes obvious, that a natural part of legal research, case preparation and problem solving consists in integrating legal solutions, principles and rules from a variety of legal levels and cultures. ${ }^{29}$ At the same time, then, the significant challenge arises from the nature of the norms which are generated in these highly specialized areas. This observation applies to each of the four areas selected here. The following examples illustrate the particular dynamics of a transnational legal-pluralist order and the challenges they pose for a traditional methodology of law at a time, where the lively assertions of an era of 'global governance' render the question of the king discipline ever more pressing. As 'legal' regulation increasingly encompasses a variety of direct and indirect, hard and soft, public and private, domestic or global types of norms, standards, recommendations and guidelines, it becomes particularly difficult to gain a perspective from which to scrutinize what Annelise Riles identified as the everpresent politics and project orientation of comparative law. The boundaries between distinctly perceived legal and political, jurisdictionally and systemically perceived systems begin to fade, while the contours of specialized, sectorial and functional regulatory regimes become more accentuated. ${ }^{30}$ In this process, different fields of law are becoming functionally differentiated in that they are asked to take on board the particular regulatory dynamics in a given regulatory area. The areas of law, which are highlighted in the following, are telling examples of how legal theory becomes intertwined with the multifaceted and complex notion - and reality - of global governance, which itself can only be unpacked from an interdisciplinary perspective. What might at first have appeared to the student as a concrete and relatively confined regulatory field - corporate governance, human rights, constitutional and administrative law - can now be seen as part of a larger conceptual and practical endeavor. For the student of comparative law, each of these fields holds the initial promise of explaining differences as well as similarities between what she might still identify as distinct, historically evolved legal cultures. A closer look, however reveals a regulatory thrust in each of these areas, which can only be scrutinized from a transnational perspective. Each of the studied 'fields' gives partial evidence of an emerging transnational regulatory landscape, which cannot exhaustively be explained from a traditional comparative perspective. The intricate coexistence of and the dynamics and tensions between different forms and levels of norms, as for example in the case of corporate governance today, illustrate the formation of a regulatory space,

\footnotetext{
${ }^{28}$ Klaus Jürgen Hopt, 'Comparative Company Law', in: Mathias Reimann and Reinhard Zimmermann (eds.), Oxford Handbook of Comparative Law (2006); David C. Donald, 'Approaching Comparative Company Law', Fordham Journal of Corporate and Financial Law, 14 (2008), 83-178.

29 Antje Wiener, 'Contested Meanings of Norms: A Research Framework', Comparative European Politics, 5 (2007), 1-17, 2: '...under conditions of transnationalization the regulatory practices of modern constitutionalism are increasingly moved out of the social contexts of their modern i.e. Hegelian conception. Subsequently, interpretation of the principles and norms of governance depends increasingly on cultural practices.'

${ }^{30}$ For the examples of transnational contract and corporate law, see Gralf-Peter Calliess and Peer Zumbansen, Rough Consensus and Running Code: A Theory of Transnational Private Law (Oxford: Hart Publishing, 2010), ch. 3, ch. 4.
} 
the confines of which are no longer congruent with jurisdictional borders. Similarly, the insights from legal anthropology into the 'practice' of human rights law ${ }^{31}$ suggest that we revisit a comparative perspective from which we would compare 'different' regulatory cultures. Of central relevance here is a legal pluralist and anthropological analysis of the ways in which human rights are identified, understood, invoked and implemented in very concrete settings. ${ }^{32}$ The last two examples, constitutional and administrative law, then, provide powerful insights into an evolving transnational regulatory landscape in that these two fields can be used as an initial toolkit with which to scrutinize both the forms (legality) and the aspirations (legitimacy) of emerging global governance institutions and practices.

\section{Comparative Corporate Governance: A Case in Point of a Transnational Legal Pluralist Order}

If there is a moment in time for comparative law, the moment to engage in comparative corporate law or, as the more recent, widely accepted parlance would have it, corporate governance, is not one, but a series in promptings to gaze across the fence. This gazing across the fence to identify and to understand the groundwork of another jurisdiction's corporate law rules has regularly been provoked by the curiosity to find out what makes another country's economy so successful. Corporate governance is widely understood to be an important part of a national economy's DNA in that it negotiates and settles, consolidates and dynamisizes the rules of the game of business creation and commercial interaction. Corporate governance relates to the exercise of powers inside the business association, or firm: the analytical focus can, for one, be directed to the relationship between the owner (shareholder; principal) and the management (agent). Alternatively, one may focus on the overall organisational structure of the firm. While this also includes the principal-agent ties, it also encompasses the other 'stakeholders' in the firm, such as employees and creditors. The first, control-oriented approach centres on shareholders as the prime residual claimants of the firm: therefore, the firm's organisation is governed by the overriding principle of maximizing 'shareholder value'. ${ }^{33}$ The other, stakeholder oriented, approach considers the actors in and around the firm and its business with regard to their vested interests in the firm. It sees the firm as embedded in a specific legal, economic and political culture, herein playing a role as societal actor. ${ }^{34}$ In contrast to the shareholder approach, this perspective takes into account the public services rendered by a large firm in view of employment capacities and overall socioeconomic spin-off. ${ }^{35}$

These two definitions lie at the base of a debate over different patterns of corporate organization, which was for the longest time driven by an almost overwhelming belief in what some recognized as nothing less than the "end of history

\footnotetext{
${ }^{31}$ See eg the contributions to Mark Goodale and Sally Engle Merry, The Practice of Human Rights: Tracking Law Between the Global and the Local (Cambridge University Press, 2006).

${ }^{32}$ Richard Ashby Wilson, 'Afterword to "Anthropology and Human Rights in a New Key": The Social Life of Human Rights', American Anthropologist, 108 (2006), 77-83.

${ }^{33}$ Michael C. Jensen, A Theory of the Firm. Governance, Residual Claims, and Organizational Forms (Harvard University Press, 2000).

34 John Parkinson, 'Models of the Company and the Employment Relationship', British Journal of Industrial Relations, 41 (2003), 481-509.

${ }^{35}$ Sanford Jacoby, 'Corporate Governance and Society', Challenge, 48 (2005), 69-87.
} 
in corporate law', ${ }^{36}$ namely the eventual triumph of the shareholder value theory. The financial and economic crisis since 2008 has done its part in challenging this credo. However, it is important to emphasize that what might be perceived as having been a dispute merely among corporate law scholars (and policy makers), had instead long become a forum with a much wider impact, as participants acknowledged the exemplary role of corporate governance for a timely and much needed scrutiny and critique of market regulation as such. ${ }^{37}$ What makes corporate governance such a promising example for the study of the prospects of comparative law, is the field's enormous regulatory dynamism, which oscillates between national historical idiosyncrasies on the one hand and the extremely volatile impulses that it receives on a global scale, on the other.

Corporate governance has to be seen in the context of a highly diversified series of transnational norm-setting processes resulting in a veritable explosion of corporate governance codes in Europe and elsewhere. With the proliferation of corporate governance codes, influenced and pushed by international and transnational activities of norm setting, discussion and thought exchange, it has become increasingly difficult to identify a single institution or author of a set of norms. Instead, much of the production and dissemination of corporate governance rules operates through the migration of standards and a cross-fertilisation of norms. A distinct feature of this de-territorialised production of norms is the radical challenge these processes pose for the way in which we distinguish between law proper and non-legal 'norms'. The dissemination of corporate governance codes, disclosure standards and rules, best practices and codes of conduct, affects the entire juridical 'nexus of corporate governance' as comprised of norms pertaining to company law, labour law and securities regulation, ${ }^{38}$ as the decentralisation of norm producers is repeated, mirrored and reflected in the hybridisation of the norms themselves. It is in this sense, that the study of the proliferation of corporate governance codes and company law production in general and of the rules of remuneration disclosure in particular feeds into a broader research inquiry into the changing face of legal regulation in globally integrated marketplaces.

Against this background, corporate governance emerges today as a product of the fundamental transformations of regulatory instruments and institutions. As corporate law is being shaped by a complex mixture of public, private, state- and nonstate-based norms, principles and rules, generated, disseminated and monitored by a diverse set of actors, ${ }^{39}$ a closer look at this field can serve two purposes: one is the way in which the analysis of contemporary corporate governance regulation can help us to assess the emerging, new framework within which corporate governance, but also other rules of market regulation are evolving. Secondly, through the way in which we begin to understand this emerging transnational regulatory framework as an illustration of contemporary rule-making, the long-standing legal pluralist contention of formal and informal legal orders comes to be seen in a new light. This leads us to

\footnotetext{
${ }^{36}$ Henry Hansmann and Reinier Kraakman, 'The End of History for Corporate Law', Georgetown Law Journal, 89 (2001), 439-468.

${ }^{37}$ See e.g. Peter A. Gourevitch and James Shinn, Political Power and Corporate Control. The New Global Politics of Corporate Governance (Princeton University Press, 2005); Peter A. Hall and David Soskice (eds.), Varieties of Capitalism. The Institutional Foundations of Comparative Advantage (Oxford University Press, 2001).

${ }^{38}$ See John W. Cioffi, Public Law and Private Power: Corporate Governance Reform in the United States and Germany in an Age of Finance Capitalism (Cornell University Press, 2010).

${ }^{39}$ See also Arthurs R. Pinto, 'Globalization and the Study of Comparative Corporate Governance', Wisconsin International Law Journal, 23 (2005), 477.
} 
re-visit the core question of any sociology of law, namely, how "to investigate the correlations between law and other spheres of culture". ${ }^{40}$ Expanding the spectrum with a view to legal pluralism might help us better understand the distinctly transnational emergence of regulatory regimes. The transnational lens allows us to study such regimes not as being entirely detached from national political and legal orders, but as both emerging from them and reaching beyond them. The transnational dimension of the new actors and the newly emerging forms of norms radicalizes their 'semi-autonomous' nature, represented in the tension between a 'formal' law and policy making apparatus on the one hand and spontaneously evolving 'informal' norms in particular social contexts on the other. ${ }^{41}$ The development of corporate governance is thus an example of intricate, domestic and transnational, multi-level processes of norm generation and norm enforcement, which poses particular challenges for a study of comparative law traditionally focusing on national legal orders. The practical relevance in stressing this transnational nature consists in radically de-parochializing the traditional comparative corporate law focus on particular national company law forms in order to lay bare the transnational connections between local law reform, deregulation and privatization processes. From this perspective, comparative corporate governance takes the respective national histories seriously, but considers them in a transnational context of increasing market self-regulatory power and an ambivalent status of the state, which is more often than not described as either a defenceless victim or as a perpetrator of the market forces of globalization.

\section{Human Rights Law and Transnational Anthropology: Unpacking Practice}

Guided by our interest in highlighting sites of transformation in traditional comparative law, the next example here considered is one where the relevance of a practical turn is perhaps even more pertinent than in the previous one. Human rights law has for the longest time been fraught with considerable tension existing between its highflying normative aspirations and its unbounded abstractness. The often cherished history of progress, redemption and alleviation has rightly been called into question, ${ }^{42}$ and what has emerged is a complex set of often intertwined and contested narratives and approaches towards human rights. Read against the background of an early relativist critique of human rights, ensuing attacks - focusing on gender blindness, structural (e.g. socio-economic) violence or colonial heritage - have helped in creating a discursive climate in which a relatively great number of euphemizing human rights assertions seems to be widely recognized as being out of step with

\footnotetext{
${ }^{40}$ E. Ehrlich, Fundamental Principles of the Sociology of Law, (orig. published in German as Grundlegung der Soziologie des Rechts, 1913) (New York: Russell \& Russell, 1962), pp. 486-506, "The Study of the living law"; G. Gurvitch, Sociology of Law, (orig. published in French as Problèmes de la sociologie du droit) (London: Routledge and Kegan Paul, 1947); M. Rheinstein, "Review: Two Recent Books on Sociology of Law [reviewing Timasheff's 'Introduction' and Gurvitch's 'Elements']", Ethics, 51 (1941), 220-231, at 221-2.

${ }^{41}$ Sally Falk Moore, 'Law and Social Change: the semi-autonomous field as an appropriate subject of study', Law \& Society Review, 7 (1973), 719-746; Julia Black and David Rouch, 'The development of global markets as rule-makers: engagement and legitimacy', Law and Financial Markets Review, (2008), 218-233.

${ }^{42}$ Amartya Sen, Development as Freedom (New York: Alfred A. Knopf, 1999); Upendra Baxi, 'Global Development and Impoverishment', in Peter Cane and Mark Tushnet (eds.), The Oxford Handbook of Legal Studies (Oxford University Press, 2003).
} 
reality and politics. Coalescing through work in international law, ${ }^{43}$ international legal history, ${ }^{44}$ literary criticism, ${ }^{45}$ cultural theory, ${ }^{46}$ political sociology, ${ }^{47}$ and legal anthropology, ${ }^{48}$ we find an intricate, multi-layered discourse on the concept and the nature of human rights, which suggests a far more differentiated approach to the problems raised by human rights assertion and practice that seems to have been possible in earlier times.

A crucial development of interest, especially in light of the here pursued research agenda to scrutinize the practical dimensions of comparative law, is the way in which new lines of inquiry are opened, due to the fact that scholars are actively pursuing and identifying sites of cross-disciplinary inquiry and shared concerns. Two developments seem highly promising in that regard: the emergence of the so-called New Legal Realism [NLR] and the increasingly influential field of ethnography of human rights law. The former is coined, in particular, by a progressive interest in making sense of two overlapping and co-evolving developments: one concerns the 'ironic turn' of the legal realist legacy, ${ }^{49}$ opening - as it were - the gates not only for critical legal studies, critical race theory or 'third world approaches to international law' but also for conservatively minded undertakings such as 'law \& economics, ${ }^{50}$ or 'social norms theory. ${ }^{51}$ The other development which NLR is interested in is the dramatic transformation of traditional, state-centred law-making: in response to the far reaching effects of privatization, deregulation and transnationalization of normgeneration, NLR seeks to revive legal sociological and legal pluralist as well as empirical and clinical law approaches to further scrutinize the nature of the emerging normative order. ${ }^{52}$ The central gist in this approach is that its proponents pursue both a methodological and a political research program. Seeing how prior assertions of the public nature of private government can easily be converted into a politically opposed policy prescription, NLR scholars demand that we take a closer look at the formal assumptions which inform the recent embrace of societal self-regulation and the primacy of 'norms' over rules. ${ }^{53}$ It becomes obvious that a most important dimension of NLR's approach is an engagement with practice in various forms. One, to be sure,

\footnotetext{
${ }^{43}$ Martti Koskenniemi, The Gentle Civilizer of Nations: The Rise and Fall of International Law 18701960 (Hersch Lauterpacht Memorial Lectures, 2002).

44 Antony Anghie, Imperialism, Sovereignty and the Making of International Law (Cambridge University Press, 2005).

${ }^{45}$ Edward W. Said, Orientalism (New York: Vintage Books, 1978).

${ }^{46}$ Arjun Appadurai, 'Disjuncture and Difference in the Global and Cultural Economy', Public Culture, 2 (1990), 1-24.

47 Boaventura de Sousa Santos, 'The Processes of Globalisation', Eurozine (2002) http://www.eurozine.com/pdf/2002-08-22-santos-en.pdf.

48 Sally Engle Merry, 'Anthropology, Law, and Transnational Processes', Annual Review of Anthropology, 21 (1992), 357-379.

${ }^{49}$ Peer Zumbansen, 'Law After the Welfare State: Formalism, Functionalism and the Ironic Turn of Reflexive Law', American Journal of Comparative Law, 56 (2008), 769-805.

50 Kerry Rittich, 'Functionalism and Formalism: Their latest Incarnations in Contemporary Development and Governance Debates', University of Toronto Law Journal, 55 (2005), 853-868, 857: "...both law and economics and critical legal studies are realist progeny."

${ }^{51}$ See e.g. Richard H. McAdams, 'The Origin, Development, and Regulation of Norms', Michigan Law Review, 96 (1997), 338-433; see also Eric A. Posner, Law and Social Norms (Harvard University Press, 2000).

${ }^{52}$ For an excellent exposition of the NLR agenda, see Gregory Shaffer and Victoria Nourse, 'Varieties of New Legal Realism: Can A New World Order Prompt A New Legal Theory?', Cornell Law Review, 61 (2009), 61-137.

${ }^{53}$ Stewart Macaulay, 'Relational Contracts Floating on a Sea of Custom? Thoughts about the Ideas of Ian Macneil and Lisa Bernstein', Northwestern University Law Review, 94 (2000), 775-804
} 
is a renewed interest in empirical legal studies, field work and the concrete study of norms in their regulatory context. ${ }^{54}$

Meanwhile, human rights law has been receiving much critique in the context of its potential cooptation within the law \& development program of the International Financial Institutions, above all the World Bank. ${ }^{55}$ A particularly powerful contribution to this critique has been mobilized by anthropologists, who have been arguing against unwarranted assumptions regarding the value and the success of human rights norms, criticizing that such assertions often occur without sufficiently taking into account the concrete contextual circumstances. ${ }^{56}$ In this vein, human rights lawyers have - in continuation of earlier suggestions ${ }^{57}$ - emphasized the need and the promise of a more empirically based, field work oriented human rights scholarship. ${ }^{58}$

Easier said than done? The currently burgeoning literature on this issue is regularly based on extensive field work, which seems to suggest that the wind may be in the sails for the ambitious undertaking to bring human rights law onto the ground of societal practice. The next step to further enhance the practical relevance of this engagement between human rights lawyers and anthropologists will likely be to continue the efforts of further approximating the methodological and normative starting points from which the respective experts embark on their collaboration. The great variances in human rights understandings and the need to expose and explore these potentials for misunderstanding are further exacerbated by the fact that the spaces in which this much-needed collaboration between human rights lawyers and anthropologists themselves constitute highly volatile and treacherous territory. As the human rights/anthropology collaboration often enough occurs in the context of funded development (or, transitional justice) projects there is an even greater need to make both assumptions and expectations explicit and to collectively pursue a continued improvement of the methodological toolkit, with which we may measure the 'success' of human rights development. The recent scrutiny of the World Bank's Indicators program is a powerful illustration of the challenges at hand. ${ }^{59}$

\section{Comparative Constitutional Law and Constitutionalism: Pipe-Dream or Prophecy?}

\footnotetext{
${ }^{54}$ Gregory Shaffer and Mark A. Pollack, 'Hard vs. Soft Law: Alternatives, Complements and Antagonists in International Governance', University of Minnesota Legal Studies Research Paper No. 09-23 (2009) http://ssrn.com/abstract=1426123.

${ }^{55}$ Alvaro Santos, 'The World Bank's Uses of the 'Rule of Law' Promise in Economic Development', in David Trubek and Alvaro Santos (eds.), The New Law and Economic Development. A Critical Appraisal (Cambridge University Press, 2006).

${ }^{56}$ Sally Engle Merry, 'New Legal Realism and the Ethnography of Transnational Law', Law \& Social Inquiry, 31 (2006), 975-995.

57 Annelise Riles, 'Anthropology, Human Rights, and Legal Knowledge: Culture in the Iron Cage', American Anthropologist, 108 (2006), 52-65; Douglas R. Holmes and George E. Marcus, 'Cultures of Expertise and the Management of Globalization: Toward the Refunctioning of Ethnography', in Aihwa Ong and S J. Collier (eds.), Global Assemblages: Technology, Politics, and Ethics as Anthropological Problems (Malden, Oxford, Carlton: Blackwell Publishing, 2005).

${ }^{58}$ Richard Ashby Wilson, 'Tyrannosaurus Lex: The Anthropology of Human Rights and Transnational Law', in Mark Goodale and Sally Engle Merry (eds.), The Practice of Human Rights: Tracking Law Between the Global and the Local (Cambridge University Press, 2006); Carol Greenhouse, 'Fieldwork on Law', Annual Review of Law and Social Sciences, (2006), 187-210.

${ }^{59}$ Sally Engle Merry, 'Measuring the World: Indicators, Human Rights, and Global Governance', in Peer Zumbansen and Ruth Buchanan (eds.), Law in Transition: Rights, Development and Transitional Justice (2009).
} 
Let us turn to our next example. Underlying the thriving field of comparative constitutional law is the assumption that we can (still) readily distinguish between 'different systems' and that it is indeed possible to reach even deeper within them in order to assess and interpret recognizable differences in the design, practice and culture of constitutional design. Much suggests, however, that the foundations on which we can base the identification and demarcation of distinct constitutional systems builds more on historic than on systematic evidence. In other words, we need to ask whether or not the increasing 'migration of constitutional ideas', 60 the phenomenon of 'judicial globalization" ${ }^{61}$ and the impregnation of constitutional cultures through 'foreign' norms and principles, ${ }^{62}$ which reflect on a considerable degree of transformation, opening and 'internationalization', still leaves the traditional comparative structure intact of comparing distinct legal cultures. ${ }^{63}$ Just as comparative law in general, constitutional comparisons, too, are still plagued by a great degree of methodological uncertainty and theoretical indeterminacy. But, while "[c]onstitutionalism is sweeping the world", ${ }^{4}$ evidenced for example by "at least 110 countries around the world" engaged in constitution writing or reform since $1990,{ }^{65}$ at a closer look this evidence is itself extremely varied. Both causes and forms of constitutional change are anything but uniform and thus belie all claims regarding a world-wide and universal trend to a specific set of constitutional values or rights. Rather, the intensity of constitutional creation, reform and discourse around the world is illustrative of the complexity of this process. The search, thus, for an analytical architecture of typologies across these myriad and continuously evolving constitutionalist cultures must reach deep into the constitutive elements of legal and political cultures, where the places, forms and scopes of democracy continue to be 'unsolved riddles.

The success of a practice of comparative constitutional law largely depends on the degree to which it becomes possible to embrace a broader, if not an alternative understanding of the nexus between the 'constitution' and an institutionalized legalpolitical order. The emergence of a transnational legal-pluralist order alluded to above can be seen as a next stage in the theorizing of comparative law. For constitutional law, this emerging transnational order underscores the necessity of looking for the constitution 'outside' the constitution, ${ }^{67}$ that is to track constitutional norms in those

\footnotetext{
${ }^{60}$ Sujit Choudhry (ed.) The Migration of Constitutional Ideas (Cambridge University Press, 2006).

${ }^{61}$ Anne-Marie Slaughter, 'Judicial Globalization', Virginia Journal of International Law, 40 (2000), 1103-1124.

${ }^{62}$ Gérard V. La Forest, 'The Expanding Role of the Supreme Court of Canada in International Law Issues', Canadian Yearbook of International Law, 34 (1996), 89; Louise Arbour and Fannie Lafontaine, 'Beyond Self-Congratulation: The Charter at 25 in an International Perspective', Osgoode Hall Law Journal, 45 (2007), 239-275.

${ }^{63}$ But see: Sujit Choudhry, 'Globalization in Search of Justification: Toward a Theory of Comparative Constitutional Interpretation', Indiana Law Journal, (1999), 819-948, 941: “A court's choice of interpretive methodology will affect more than the outcome the particular case before it. It will also likely affect the broader constitutional culture of the interpreting court's jurisdiction."

${ }^{64}$ Susan H. Williams, 'Introduction: Comparative Constitutional Law, Gender Equality, and Constitutional Design', in Susan H. Williams (ed.) Constituting Equality. Gender Equality and Comparative Constitutional Law (Cambridge University Press, 2009), p. 1.

${ }^{65}$ Ibid.

${ }^{66}$ Susan Marks, The Riddle of All Constitutions. International Law, Democracy, and the Critique of Ideology (Oxford University Press, 2000), pp. 103, 146.

${ }^{67}$ See eg Ernest A. Young, 'The Constitution outside the Constitution', Yale Law Journal, 117 (2007), 408-473, and already Robert M. Cover, 'Nomos and Narrative', Harvard Law Review, 97 (1983), 4-68.
} 
regulatory structures, where questions of legitimacy are at stake. Comparative constitutional law scholars have begun to embrace such a broader understanding of their field by adopting the term of 'constitutionalism'. ${ }^{68}$ Through this lens, a constitutional scholar might recognize the evolution of a transnational culture of constitutionalism. When speaking of transnational constitutionalism, we should not think of a normative order that emerges autonomously outside of the confines of the nation state and, as such encompasses a distinct space of global governance with no relation to the world of states and the correlating measurements of law, namely national and international. Instead, transnational constitutionalism expresses the continuing evolution of constitutional principles, instruments and doctrines as a particular form of legal evolution today. Transnational constitutionalism radically challenges but does not negate the distinction between the domestic and the international legal order. Again, to reiterate Jessup's emphasis of a transnational legal order, the idea of 'transnational law' could aptly capture the emergence of norm creation and enforcement outside of the confines of both private and public international law. ${ }^{69}$ Central to the ensuing projects, prominently in the theoretical and conceptual work around legal pluralism, ${ }^{70}$ human rights law ${ }^{71}$ and transnational legal theory, ${ }^{72}$ are two insights, one relating to the overwhelming evidence of norm creation which occurs outside of the state's law-making apparatus, ${ }^{73}$ the other one connected to a particular understanding of law's relation to society, where society is understood to be one 'without centre or apex' ${ }^{74}$ In such a society, the state represents a particular emblematic form of political organization the emergence (and fate) of which is historically embedded and thus contingent. That the centre (or, the top) of societies should be occupied by the state is - thus - both historically and geographically variable.

While the consequences for traditional comparative law are substantial, there is today prolific evidence of comparative constitutional studies 'in action', as long as courts stick to comparing elements taken from distinct public law regimes and constitutional orders. Courts around the world - with differing degrees of deference ${ }^{75}$ - have long been engaged in practiced comparison, as they consider drawing on

\footnotetext{
${ }^{68}$ Norman Dorsen, Michel Rosenfeld, András Sajó and Susanne Baer, Comparative Constitutionalism. Cases and Materials. 2nd ed. (West, 2010).

${ }^{69}$ Philip C. Jessup, Transnational Law; Wolfgang G. Friedmann, 'Corporate Power, Government by Private Groups, and the Law', Columbia Law Review, 57 (1957), 155-186.

${ }^{70}$ Gunther Teubner, "Global Bukowina': Legal Pluralism in the World Society', in Gunther Teubner (ed.) Global Law Without a State (Dartmouth Publishing Group, 1997); Sally Engle Merry, 'New Legal Realism and the Ethnography of Transnational Law', Law \& Social Inquiry, 31 (1997), 975-995; Paul Schiff Berman, 'The New Legal Pluralism', Annual Review of Law and Social Sciences, (2009), 225242.

${ }^{71}$ Craig M. Scott, 'Introduction to Torture as Tort'; Harold Hongju Koh, 'Transnational Legal Process', Nebraska Law Review, 75 (1996), 181-206.

${ }^{72}$ Craig M. Scott, "Transnational Law' as Proto-Concept: Three Conceptions', German Law Journal, 10 (2009), 859-876; Peer Zumbansen, 'Transnational Law', in Jan Smits (ed.) Encyclopedia of Comparative Law (Cheltenham, Northampton: Edward Elgar Publishing Limited, 2006).

${ }^{73}$ Sally Engle Merry, 'Legal Pluralism', Law \& Society Review, 22 (1988), 869-901; Marc Galanter, 'Farther Along', Law \& Society Review, 33 (1999), 1113-1123.

${ }^{74}$ Niklas Luhmann, Political Theory in the Welfare State [1981, transl. by John Bednarz Jr.] (de Gruyter, 1990).

${ }^{75}$ Consider the 'controversy over citation', Dorsen et al, supra, $6 \mathrm{ff}$; see also the discussion of the 'living constitution' and the 'constitution as living tree' metaphors in Vicki C. Jackson, 'Constitutions as 'Living Trees'? Comparative Constitutional Law and Interpretive Metaphors', Fordham Law Review, 75 (2006), 921-960, $941 \mathrm{ff}$.
} 
alternative, 'foreign' viewpoints in preparing and rendering their decisions. ${ }^{76}$ In that practice, 'foreign' constitutional law is seen as both a guidance to local decisionmaking and as a 'work of art'. 77

But, the reference points for comparative constitutional law begin to lapse both internally within the nation state and beyond. The current phase of globalization is marked by a far-reaching change in the position and status of states and sovereign political actors. The changes brought about for statehood since the second World War, through decolonization and regionalization, reunification and emancipation ${ }^{78}$ have drastically changed the anchoring and reference points for comparative constitutional studies: "The transformation of statehood shatters the former unity of territory, power, and people, and challenges the constitution's ability comprehensively to encompass the political entity of the state." ${ }^{, 79}$ From the perspective, then, of the constitution's close association of the constitution and constitutionalism with the state, the prospects of comparative constitutional law seem to be tightly connected to the fate of comparative law in a globalized world, where the contours of statehood have become porous. ${ }^{80}$ Arguably, the relevance of the concept of 'constitutionalism' - as opposed to 'constitution' - lies in its potential to build bridges between the constitutional law discourses within the nation state and the investigations into legitimacy of global governance in the "post-national constellation."

Another development in transnational law making is of great significance in assessing the prospects of comparative constitutional law. The 'emergence of private authority in global governance ${ }^{82}$ - as expressed in a variety of areas ${ }^{83}$ including

\footnotetext{
${ }^{76}$ Lawrence v. Texas, 123 S. Ct. 2472, 2481 (2003); Ruti Teitel, 'Comparative Constitutional Law in a Global Age', Harvard Law Review, 117 (2004), 2570-2596; for a skeptical view: Christopher McCrudden, 'A Common Law of Human Rights? Transnational Judicial Conversations on Constitutional Rights', Oxford Journal of Legal Studies, 20 (2000), 499-532.

${ }^{77}$ Alexandra Kemmerer, 'Constitutional Law as Work of Art - Experts' Eyes: Judges of the World Examine the Constitution of Europe', German Law Journal, 4 (2003), 859-862.

${ }^{78}$ Craig Scott and Peer Zumbansen, 'Foreword: Making a Case for Comparative Constitutionalism and Transnational Law', Osgoode Hall Law Journal, 46 (2006), vii-xix; Michel Rosenfeld, 'Rethinking constitutional ordering in an era of legal and ideological pluralism', International Journal of Constitutional Law, 6 (2008), 415-455; Timothy Brennan, 'Postcolonial Studies and Globalization Theory', in Revathi Krishnaswarmy and John C. Hawley (eds.), The Post-Colonial and the Global (University of Minnesota Press, 2008), pp. 37 ff, 39, highlighting the normative bias of modern globalization writing: "The "now' is the new, and the new is rapturously and exuberantly embraced."

${ }_{79}$ Petra Dobner, 'More Law, less Democracy? Democracy and Transnational Constitutionalism', in Petra Dobner and Martin Loughlin (eds.), The Twilight of Constitutionalism? (Oxford University Press, 2010), p. 141.

80 David Kennedy, 'New Approaches to Comparative Law: Comparativism and International Governance', Utah Law Review, (1997), 545-637; Christopher A. Whytock, 'Taking Causality Seriously in Comparative Constitutional Law: Insights from Comparative Politics and Comparative Political Economy', Loyola of Los Angeles Law Review, 41 (2008), 629-682.

${ }^{81}$ Jürgen Habermas, The Postnational Constellation (The MIT Press, 2001); Jürgen Habermas, 'A Political Constitution for the Pluralist World Society?' in Jürgen Habermas (ed.) Between Naturalism and Religion. Philosophical Essays (Cambridge: Polity Press, 2008).

${ }^{82}$ R. Hall and T. Biersteker (eds.), The Emergence of Private Authority: Form of Private Authority and their Implications for International Governance (Cambridge University Press, 2001); see also N. Jansen, The Making of Legal Authority (Oxford University Press, 2010).

${ }^{83}$ David Schneiderman, 'Investment Rules and the New Constitutionalism', Law \& Soc Inquiry, 25 (2000), 757-783; Timothy J. Sinclair, 'Passing Judgment: Credit Rating Processes as Regulatory Mechanisms of Governance in the Emerging World Order', Review of International Political Economy, 1 (1994), 133-159; Dieter Kerwer, 'Holding Global Regulators Accountable: The Case of Credit Rating Agencies', Governance, 18 (2005), 453-475; Harm Schepel, The Constitution of Private Governance. Product Standards in the Regulation of Integrating Markets (Oxford: Hart Publishing, 2005); Berthold Goldman, 'Frontières du droit et 'lex mercatoria", Archives de la Philosophie de Droit, 13 (1964), 177-
} 
standardization $^{84}$ and the lex mercatoria ${ }^{85}$ - constitutes a considerable challenge for constitutional thought. These regulatory regimes in the transnational arena reflect, on the one hand, on a fundamentally changed role of the state in the exercise of 'public' authority ${ }^{86}$, the origins of which have to be seen, firstly, in a transformation of the inter-national context ${ }^{87}$ and in the inner-state shift 'from government to governance. ${ }^{88}$ Secondly, these changes are associated with the emergence of normmaking processes, institutions of rule creation, implementation and adjudication which scholars are struggling to fully scrutinize. Negotiating their allegedly 'autonomous' nature ${ }^{89}$ 'without ${ }^{90}$ or 'beyond" ${ }^{91}$ the state, legal scholars, political philosophers and sociologists are equally faced with the following question: "Is constitutional theory able to generalize the ideas it developed for the nation state and to re-specify them for today's problems? In other words, can we make the tradition of nation-state constitutionalism fruitful and redesign it in order to cope with phenomena of privatization and globalization?",92

Such questions unfold against the background of the two contexts of transformation - the international and the national one. That the field of comparative (constitutional) law, despite pertinent enterprises to scrutinize its methodological foundations, ${ }^{93}$ still lacks satisfactory theoretization, has been remarked by scholars all

192; Klaus Peter Berger (ed.) The Practice of Transnational Law (The Hague, London, Boston: Kluwer Law International, 2001); for a critique, see Thomas Schultz, 'Some Critical Comments on the Juridicity of Lex Mercatoria', X Yearbook of Private International Law, (2008), 667-710; Peer Zumbansen, 'Piercing the Legal Veil: Commercial Arbitration and Transnational Law', 8 European Law Journal, (2002), 400-432; Gralf-Peter Calliess and Peer Zumbansen, Rough Consensus and Running Code: A Theory of Transnational Private Law (Oxford: Hart Publishing, 2010).

${ }^{84}$ Nils Brunsson and Bengt Jacobsson, A World of Standards (Oxford University Press, 2000).

${ }^{85}$ A. Claire Cutler, Private Power and Global Authority: Transnational Merchant Law in the Global Economy (Cambridge University Press, 2003).

${ }^{86}$ Armin von Bogdandy, Philipp Dann and Matthias Goldmann, 'Developing the Publicness of Public International Law', German Law Journal, 9 (2008), 1375-1400.

${ }^{87}$ See eg Robert O. Keohane and Joseph S. Nye, 'Introduction', in Joseph S. Nye and John D. Donahue (eds.), Governance in a Globalizing World (Brookings Institution Press, 2000), Myres S. McDougal and W. Michael Reisman, 'The World Constitutive Process of Authoritative Decision', in Myres S. McDougal and W. Michael Reisman (eds.), International Law Essays (1981) and John M. Hobson, The State and International Relations (Cambridge University Press, 2000).

${ }^{88}$ Mark Bevir, R.A.W. Rhodes and Patrick Weller, 'Traditions of Governance: Interpreting the Changing Role of the Public Sector', Public Administration, 81 (2003), 1-17; Alfred Aman Jr., 'Law, Markets and Democracy: A Role for Law in the Neo-Liberal State', New York Law School Review, 51 (2007), 801-815; Rod A. W. Rhodes, 'Waves of Governance', in David Levi-Faur (ed.) Oxford Handbook of Governance (Oxford University Press, 2011).

${ }^{89}$ Berthold Goldman, 'Frontières du droit et 'lex mercatoria", Archives de la Philosophie de Droit, 13 (1964), 177-192; Klaus Peter Berger, The Practice of Transnational Law; for a critique, see Thomas Schultz, 'Some Critical Comments on the Juridicity of Lex Mercatoria', X Yearbook of Private International Law, (2008), 667-710; Peer Zumbansen, 'Piercing the Legal Veil: Commercial Arbitration and Transnational Law', European Law Journal, 8 (2002), 400-432; Gralf-Peter Calliess and Peer Zumbansen, Rough Consensus and Running Code.

${ }^{90}$ Gunther Teubner, "Global Bukowina': Legal Pluralism in the World Society', in Gunther Teubner (ed.) Global Law Without a State (Dartmouth Publishing Group, 1997).

${ }^{91}$ Ralf Michaels, 'The True New Lex Mercatoria: Law Beyond the State', Indiana Journal of Global Legal Studies, 14 (2007), 447-468.

${ }^{92}$ Gunther Teubner, 'Fragmented Foundations: Societal Constitutionalism beyond the Nation State', in Petra Dobner and Martin Loughlin (eds.), The Twilight of Constitutionalism? (Oxford University Press, 2010), p. 328 .

${ }^{93}$ H. Patrick Glenn, 'Comparative Legal Families and Comparative Legal Traditions', in Mathias Reimann and Reinhard Zimmermann (eds.), Oxford Handbook of Comparative Law (Oxford 
around. $^{94}$ More importantly and substantively more fruitfully, scholars have highlighted the importance of a forceful engagement with the methodological challenges arising from any comparative legal project today. ${ }^{95}$ Connecting the current inquiry in comparative constitutionalism with the observations made above with regard to human rights ethnography, the next step must be to bring together the evolving understanding of an emerging transnational legal-pluralist order with the insights into the necessity of grounding abstract concepts of any form of rights and legal regulation in concrete societal contexts. From this perspective, it would be necessary, in a first step, to make explicit the different starting points and background assumptions concerning the elements of a constitutional order considered crucial. In a second step it would be necessary to take into view the manifold manifestations of 'rights' talk as they occur after or around far reaching political turmoil. A characteristic of this reference to rights is that it occurs more often than not without rights themselves being mentioned because participants employ highly varied forms of legal semantics through which they hope to gain an 'access to justice'. The practical relevance of comparative constitutional law would reveal itself in the ability to lay bare different forms in which constitutional claims break through and come to the fore, often enough in non easily recognized 'constitutional' parlance, but in idiosyncratic, context specific and local language. The work, for example, on 'globalization from below' ${ }^{96}$ or on 'transnational labor citizenship" ${ }^{97}$ can be seen as providing instantiations of constitutional law in action, without there being an overly explicit emphasis on the constitutional nature of the legal regime at question. At the same time, it is important to keep in mind that such a non-traditionalist look at the lingering constitutional forces 'beneath the ground' is in no way privy recent ethnographic or legal pluralist scholarly endeavors alone. Quite to the contrary, progressive scholars had long fostered an awareness of those constitutional forces 'in the dark', or as being outside of regular constitutional doctrine. ${ }^{98}$ It is a well known fact, that the difference between 'sovereignty' and 'property' is a mere choice of wording. 99

\section{Comparative Administrative Law as Sleeping Beauty: Should We Kiss Her?}

\footnotetext{
University Press, 2006), and Professor Glenn's groundbreaking textbook, soon to be published in its fifth edition.

${ }^{94}$ Ran Hirschl, 'The Question of Case Selection in Comparative Constitutional Law', American Journal of Comparative Law, 53 (2005), 125-155.

${ }^{95}$ Russell A. Miller, 'Introduction', in Abdullah Ahmed An-Naim, Michael J. Bazyler, Russell A. Miller and Peter $\mathrm{Yu}$ (eds.), Global Legal Traditions: Comparative Law in the Twenty-First Century (LexisNexis, 2011), who draws on Patrick Glenn's concept of legal traditions to argue that "the answer must be that legal tradition need not be the object of a comparative undertaking, but instead might be part of the inquiry to be made in better understanding the laws or legal institutions that eventually become the objects of comparison."

${ }^{96}$ Boaventura de Sousa Santos and César A. Rodríguez-Garavito (eds.), Law and Globalization from Below. Towards a Cosmopolitan Legality (Cambridge University Press, 2005).

97 Jennifer Gordon, 'Transnational Labor Citizenship', Southern California Law Review, 80 (2007), 503-587.

${ }^{98}$ See eg Ernest A. Young, 'The Constitution outside the Constitution', Yale Law Journal, 117 (2007), 408-473; see already Karl N. Llewellyn, 'The Constitution as Institution', Columbia Law Review, 34 (1934), 1-52, and Crawford Brough Macpherson, 'The Rise and Fall of Economic Justice', (1987) in: Macpherson, The Rise and Fall of Economic Justice, and other Essays. The role of state, class and property in twentieth-century democracy (Oxford University Press, 1985), pp. 1-20.

${ }^{99}$ Morris R. Cohen, 'Property and Sovereignty', Cornell Law Quarterly, 13 (1927), 8-30.
} 
The last example chosen here to explore the potential of a 'turn to practice' in comparative law is prompted by the recently emerged scholarly activity focusing on so-called Global Administrative Law [GAL]. ${ }^{100}$ While this ambitious research project has met with both interest and considerable skepticism, ${ }^{101}$ one particular trait has not to my knowledge - been made part of extensive scrutiny. This concerns the project's surprising lack of a comparative basis as regards countries' administrative law doctrine. Born out of a serendipitous collaboration between two public lawyers educated in the common law and a young civil law scholar, GAL nevertheless shows very little if any traces of this background - neither within the founding group of scholars nor in the intellectual basis of the project itself. As a research project with a global aspiration, focusing above all on the troubling insufficiencies in global democratic governance, as instantiated by the World Bank, the International Monetary Fund or the World Trade Organization, the request, hinted at here, for the project to incorporate a comprehensive comparative agenda might simply be ill-directed. At the same time, it gives pause to think that a project with such far reaching scope can be conceived in near to complete isolation of the historical-intellectual contexts in which the very concepts, which are now at the centre of the project - participation, transparency and judicial review ${ }^{102}$ - have their origin. If we considered, for a moment, the striking coincidence of, say, the publication of two important writings in both the US American and the German administrative law sciences, in $1938,{ }^{103}$ we would perhaps become tempted to dig deeper. Such digging might in fact not only reveal the background assumptions of GAL as (whose?) administrative law 'goes global', but it could also go a long way in helping us understand the potential of bringing the hidden histories of a particular legal field to light, as they feed into the conceptualization on a world scale.

Given the different histories and narratives that inform national understandings of administrative law, with which we embark on any comparison of administrative regimes or, with which we begin to address the regulatory challenges posed by international organizations under the rubric 'Global Administrative Law', we should have a closer look at both the available instruments in comparative law and the subject matter - administrative law - itself. Close readings of national narratives of administrative governance reveal particular connotations of regulatory power and of the relationship between different institutions (legislature, executive, judiciary and administrative agencies). ${ }^{104}$ What emerges of such side-by-side inspections of national narratives, is that particular assessments of administrative governance are based on a

\footnotetext{
${ }^{100}$ Benedict Kingsbury, Nico Krisch and Richard Stewart, 'The Emergence of Global Administrative Law', Law \& Contemporary Problems, 68 (2005), 15-61.

101 B.S. Chimni, 'Co-option and Resistance: Two Faces of Global Administrative Law', New York University Journal of International Law \& Politics, 37 (2005), 799-827; Carol Harlow, 'Global Administrative Law: The Quest for Principles and Values', European Journal of International Law, 17 (2006), 187-214; Karl-Heinz Ladeur, 'The Evolution of General Administrative Law and the Emergence of Postmodern Administrative Law', Osgoode Hall Law School, 6 (2011); CLPE Research Paper Series SSRN.

${ }^{102}$ Kingsbury, 'The Emergence of Global Administrative Law'.

${ }^{103}$ See, on the one hand, James W. Landis, The Administrative Process (Greenwood Press, 1938), and, on the other, Ernst Forsthoff, 'The Administration as Provider of Services (transl. from Der Staat der Daseinsvorsorge, 1938)', in Arthur J. Jacobson and Bernhard Schlink (eds.), Weimar. A Jurisprudence in Crisis (University of California Press, 2000).

104 JAMES W. LANDIS, THE ADMINISTRATIVE PROCESS.
} 
particular understanding of the relationship between state and society, between public and private and between citizen and state. ${ }^{105}$

This is powerfully exemplified by the understanding of the public-private distinction with regard to the nature of the administrative process. One could argue, from an Anglo-American perspective that conceptions of the administrative process in the 1930s would serve to free up space for reform projects from the stronghold of legalistic control and judicial review. Here, the critique of a concept, based on which regulation of an otherwise self-regulating market would happen through general principles, eventually promoted the view that not courts, but rather highly educated and flexible administrative actors could effectively "handle the regulatory problems of a complex, interdependent, industrial society." 106 The attention shifted towards a political assessment of this 'scientific' expertise and was soon complemented by an emphasis on the use of administrative action to promote social justice, a task for which courts were seen to be insufficiently sensitive. ${ }^{107}$

In contrast to this we find a somewhat different concept in German administrative law. In the latter, the public-private distinction would for the longest time shape an understanding of the state resting on top of society and in constant danger of being captured by diverse, powerful societal interests. This image of society as beleaguering and eventually consummating the state was powerfully painted again in 1938 by Carl Schmitt's LEVIATHAN (1938) and by one of Schmitt's master pupils, the constitutional historian and administrative law scholar, Ernst Forsthoff, who published in the same year his succinct proposal for a responsible and powerful state to assume responsibility for administering the needs of society, in "Der Staat der Daseinsvorsorge". ${ }^{108}$ Certainly, administrative law in Germany had already for a long time been losing its innocence and elevated status vis-à-vis society through the ever increasing regulation of an industrializing society and, subsequently, a war economy. Debates among German administrative lawyers over the state of their discipline became heated as they would always unfold with close links to reflections over the sovereignty of state rule.

To be sure, 'total state' thinking ${ }^{109}$ remained an extreme position in German public law thinking. ${ }^{10}$ A consequence drawn in German legal scholarship after 1945 was to demand that all administrative action be placed under close scrutiny by courts. ${ }^{111}$ The protection of the individual citizen from acts by the government was

\footnotetext{
105 See eg Gerald Frug, 'The Ideology of Bureaucracy in American Law', Harvard Law Review, 97 (1983), 1277-1388; Dieter Grimm, 'Reformalisierung des Rechtsstaatsprinzips als Demokratiepostulat', Juristische Schulung [JuS], 20 (1980), 704; Michael Stolleis, 'Entwicklungsstufen der Verwaltungsrechtswissenschaft', in Wolfgang Hoffmann-Riem, Eberhard Schmidt-Assmann and Andreas Voßkuhle (eds.), Grundlagen des Verwaltungsrechts. Band I: Methoden. Maßstäbe. Aufgaben. Organisation (Beck Juristischer Verlag, 2006).

106 MORTON J. HORWITZ, THE TRANSFORMATION OF AMERICAN LAW 1870-1960 (Oxford University Press, 1992), pp. 221.

${ }^{107}$ Id., at 225 .

${ }^{108}$ See, above, note 103 .

${ }^{109}$ Ernst Forsthoff, 'The Total State (excerpts of the 1933 volume)', in Arthur J. Jacobson and Bernhard Schlink (eds.), Weimar. A Jurisprudence in Crisis (University of California Press, 2000).

${ }^{110}$ Fritz Ossenbühl and Klaus Lange, 'Grundlagen des Verwaltungsrechts', Die Verwaltung, 40 (2007), 125-140, 126: "Die Verwaltungsrechtswissenschaft im Deutschland der Nachkriegszeit war im Grunde durch das Trauma einer unter Willkürverdacht stehenden Exekutive geprägt. Und dieses Trauma hatte Tradition, auch schon aus der absolutistischen Zeit. Es bestimmte Thema und Zuschnitt der Verwaltungsrechtswissenschaft.“"

${ }^{111}$ Id.; see also Michael Stolleis, 'Entwicklungsstufen der Verwaltungsrechtswissenschaft', in Wolfgang Hoffmann-Riem, Eberhard Schmidt-Assmann and Andreas Voßkuhle (eds.), Grundlagen des
} 
considered essential. The eventually emerging welfare state orientation in German public law, arising out of an amalgamation of growing regulatory demands in areas such as environmental law but also in labor and social law, brought about a subtle shift in the law's orientation.

In a conservative tradition, a formalist rule of law concept of the Bonn Republic after 1949 had to be defended against the contentions of the social and welfare state, a debate which found its temporary climax during the 1952 German public lawyers association meeting, triggering the so-called Forsthoff-Abendroth debate that focused on the constitutionality under the German Basic Law to codify social rights. ${ }^{112}$ Well into the 1970 s, thus, administrative law remained within a conservative ambit. In short, it remained a field for public lawyers, mandated with the elaboration and consolidation of reliable rules for the resolution of difficult regulatory problems. The state and its the administrative agencies were still being understood and conceptualized as institutionally and normatively removed from civil society. The resulting, somewhat impoverished concept of society present in German social theory might have been captured perfectly by Jürgen Habermas, who remarked that for the longest time 'society' has been available only as a deduced concept, which had no definition of its own, but had to be seen as resulting from subtraction from the state. ${ }^{113}$ As already alluded to with respect to the emerging regulatory demands of a fast economically and dramatically industrializing post-war society, it was quickly perceived that the administration would inevitably play an important role within the new regulatory paradigm. ${ }^{114}$ Methodologically, this is most powerfully expressed in the shift from conditional planning to a final, goal-oriented planning paradigm. While politics formulated the orientation of governmental action, it was left to the administration to choose the appropriate means to pursue these goals. ${ }^{115}$

Taking even a cursory comparative view on the administrative law developments in Germany and in the United States reveals thus a host of striking similarities, many of which are owed to the crisis of formalism that accompanied the increase of public regulation in more and more areas of societal life. ${ }^{116}$ The critique of 'classical legal thought', ${ }^{117}$ unfolded in both countries with great strength. The involvement of the state in many areas of societal life lead to the emergence of new fields of administrative law (e.g. 'social law' encompassing workmen's insurance etc;

Verwaltungsrechts. Band I: Methoden. Maßstäbe. Aufgaben. Organisation (Beck Juristischer Verlag, 2006), p. 110, highlighting the changing role of the citizen, no longer perceived as object of state regulation, but as subject and bearer of 'rights'.

112 Reprinted in Ernst Forsthoff (ed.), RECHTSSTAATLICHKEIT UND SOZIALSTAATLICHKEIT (Wissenschaftliche Buchgesellschaft Darmstadt, 1968).

113 Jürgen Habermas, The Postnational Constellation; see also Niklas Luhmann, 'Gesellschaftliche und politische Bedingungen des Rechtsstaates, in: Niklas Luhmann, Politische Planung. Aufsätze zur Soziologie von Politik und Verwaltung (VS Verlag, 2007 ), pp. 53-65.

${ }^{114}$ Michael Stolleis, 'Entwicklungsstufen der Verwaltungsrechtswissenschaft', in Wolfgang HoffmannRiem, Eberhard Schmidt-Assmann and Andreas Voßkuhle (eds.), Grundlagen des Verwaltungsrechts. Band I: Methoden. Maßstäbe. Aufgaben. Organisation (Beck Juristischer Verlag, 2006), pp. 112-115.

${ }^{115}$ Michael Stolleis, 'Entwicklungsstufen der Verwaltungsrechtswissenschaft', p. 114.

${ }^{116}$ Michael Stolleis, A History of Public Law in Germany 1914-1945 (Thomas Dunlop transl.) (Oxford University Press, 2004), 199: "[t]he state appeared as dangerously incapable of making decisions vis-àvis the society that was occupying it, but also as ubiquitous in a burdensome way. Society seemed to meddle in the state, and at the same time the weak and ever more demanding individual was dependent on state services in a new kind of way".

${ }^{117}$ Duncan Kennedy, 'Three Globalizations of Law and Legal Thought: 1850-2000', in David Trubek and Alvaro Santos (eds.), The New Law and Economic Development (Cambridge University Press, 2006), pp. 26, 31; see also Duncan Kennedy, 'From the Will Theory to the Principle of Private Autonomy: Lon Fuller's 'Consideration and Form", Columbia Law Review, 100 (2000), 94-175. 
communal law, taxation law, labor law etc). The thriving of administrative science led one of the major leading German administrative lawyers to remark in 1924, that "constitutional laws pass, administrative law stays." 118 Erich Kaufmann, one of the central figures in the public law debate during the Weimar Republic, remarked fittingly: "In this development there is no return to the classic administrative state.",119

What can be seen then through a comparative lens is that the critique of formalism as it unfolded in the U.S. American context around the work of James Landis unfolded with a political thrust that was on the other end of the spectrum than that which accompanied the strengthening of the administrative branch in Germany: Landis's progressive rescue of administrative governance is juxtaposed to Forsthoff's liberation of a conservative bureaucracy from parliamentary and judicial oversight. Indeed, the interesting feature of such a comparison is that the respective turn away from formalism, which accompanied the rise of welfare state regimes in both countries remains embedded and can adequately be explained only with reference to the particular political economy of "state and society" and its practical and symbolic power in each respective legal and socio-economic culture. In short, then, a comparative study of state and society in Germany and in the United States reveals a marked contrast in the way in which lawyers did elaborate legal concepts in relation to their understanding of state and society. In turning its attention to the recent decades, such a comparative administrative history would have to ask questions regarding the different or similar experiences in welfare state reform, privatization and internationalization. Against this background, the distinct starting points and trajectories of administrative governance experiences would become visible.

With regard to the ambitious project of conceptualizing a global administrative law, such a glance at the legal and intellectual history of governance ideas reveals a considerable degree of complexity in the respective trajectories of national administrative law traditions. As GAL continues to become more sophisticated, not least due to the impulses and critique it receives from different sides, most prominently perhaps critical international law scholarship ${ }^{120}$ and the Third World Approaches to International Law, ${ }^{121}$ its current blindness to national administrative law histories will need to be addressed - sooner rather than later. The still outstanding face-to-face dialogue and reciprocal engagement between the original GAL concept on the one hand and the 'Public Authority' project under the auspices of the Max Planck Institute for International Law in Heidelberg, ${ }^{122}$ on the other, is telling in that regard. Meanwhile, some of its most insightful critics have been pointing to the ghosts in the architecture, forcefully bringing to light the problematic tensions between a de-nationalized construction of an administrative governance framework

\footnotetext{
${ }^{118}$ Otto Mayer, preface to Verwaltungsrecht, $3^{\text {rd }}$ ed. (Berlin: Duncker \& Humblot, 1924), referred to in STOLLEIS, HisTORY, at 199.

119 Erich Kaufmann, in: 6 VERÖFFENTLICHUNGEN DER VEREINIGUNG DER DEUTSCHEN STAATSRECHTSLEHRER 152 (1929), cited in STOLLEIS, HistORY, p. 206.

${ }^{120}$ Susan Marks, 'Naming Global Administrative Law', New York University Journal of International Law and Politics, 37 (2005), 995-1001.

${ }^{121}$ B.S. Chimni, 'Co-option and Resistance: Two Faces of Global Administrative Law', New York University Journal of International Law \& Politics, 37 (2005), 799-827; Obiora Chinedu Okafor, 'Critical Third World Approaches to International Law (TWAIL): Theory, Methodology, or Both?', International Community Law Review, 10 (2008), 371-378.

${ }_{122}$ Armin Bogdandy, Philipp Dann and Matthias Goldmann, 'Developing the Publicness of Public International Law', German Law Journal, 9 (2008), 1375-1400. The entire issue can be accessed at: http://www.germanlawjournal.com/index.php?pageID=13\&vol=9\&no=11.
} 
on the one hand and the intricate and concrete histories of this very governance on the ground. ${ }^{123}$

\section{Concluding Remarks}

In trying to elaborate on the tension between theory and practice in comparative law, this chapter has, in exemplary fashion, focused on four areas that offer valuable insights into the conceptual value and practicality of currently pursued comparative law projects. In light of the inseparability of the conceptual foundations of each project from its practical dimensions, I want to argue for a bolder consideration of 'what is at stake' in each of these projects. The examples alluded to above comparative corporate governance, human rights and legal anthropology, comparative constitutionalism and global administrative law - all have in common that they are key intellectual endeavors in the present global governance discourse. While 'global governance' still provokes considerable excitement as a term allegedly in need of a definition - something well known from the most recent surge in 'globalization studies' since the early 1990 s - the caravan has clearly moved on. Global governance is as much a reality as it is a semantical construction. One way to unpack its many dimensions in a very practical and political manner would be to mobilize from the ground up the many comparative stories, which are at this point still strangely neglected in the rush into the global space.

${ }^{123}$ Carol Harlow, 'Global Administrative Law: The Quest for Principles and Values', European Journal of International Law, 17 (2006), 187-214; Carol Harlow, 'European Administrative Law and the Global Challenge', in Paul Craig and Gráinne de Búrca (eds.), The Evolution of EU Law (Oxford University Press, 1999); Carol Harlow, 'The 'Hidden Paw' of the State and the Publicisation of Private Law', in David Dyzenhaus, Murray Hunt and Grant Huscroft (eds.), A Simple Common Lawyer. Essays in Honour of Michael Taggart (Oxford: Hart Publishing, 2009). 